\title{
ORGANIZATIONAL CULTURE OF THE WAR STUDIES UNIVERSITY IN OPINION OF STUDENTS OF THE FACULTY OF MANAGEMENT AND COMMAND
}

\author{
Marlena NIEMIEC \\ War Studies University, Department of Management and Command, Department of Management of Public \\ Organizations, m.niemiec@akademia.mil.pl, ORCID: 0000-0001-6025-1862
}

Purpose: The purpose of the paper is to present the of the opinions of students of the War Studies University about its organizational culture. Recently, the War Studies University has undergone a number of changes that affect on various areas of its operation. When considering the organizational culture of the War Studies University, special attention should be paid to the fact that it was established in 2016 in place of the National Defence University. In October 2019, three years have passed since this event. Here came the idea to develop an article that put special emphasis on the issue of organizational culture of the War Studies University in the opinion of its students who entered the Faculty of Management and Command. The research undertaken is of a pilot nature.

Design/methodology/approach: The study involved 114 second degree students, full-time 61 students (53.51\%) and part-time 53 people (46.49\%) of the Faculty of Management and Command at the War Studies University. The study was conducted in June 2019. The survey questionnaire was used for the research.

Findings: The results of this survey allowed to identify the students of the Faculty of Management and Command are able to identify, perceive those factors, elements and events that have a direct impact on the functioning of students in their role, while assessing these changes as important or very important.

Originality/value: The author of this article presents the results of research on organizational culture in relation to the opinions of students of the Faculty of Management and Command. War Studies University in 2016 was transformed from the National Defense University.

Keywords: organizational culture, changes in organization, War Studies University.

\section{Introduction}

Recently, the War Studies University has undergone a number of changes that affect on various areas of its operation. When considering the organizational culture of the War Studies University, special attention should be paid to the fact that it was established in 2016 in place 
of the National Defense University. In October 2019, three years have passed since this event. Here came the idea to develop an article that put special emphasis on the issue of organizational culture of the War Studies University in the opinion of its students who entered the Faculty of Management and Command. The research undertaken is of a pilot nature. They are intended to attempt to diagnose whether the changes that have taken place, as well as the changes that have been implemented since October 2019 in the Higher Education Act have any impact on the organization which is the University.

There is no doubt that the issues discussed in this article are quite difficult to examine, because they relate to the organizational culture, organizational identity of the university, which boasts glorious traditions, including Higher Military School and on the other hand is subject to transformation and introduces changes resulting from the law on higher education.

In the considerations it was decided to solve the main research problem expressed in the form of the question:

How are changes in the organizational culture of the War Studies University perceived by students of the Faculty of Management and Command?

The main problem formulated this way became the cause to generate the following specific problems expressed in the form of questions:

1. Which of the factors identified with organizational culture affect on its organizational culture at the War Studies University?

2. How do the students of the Faculty of Management and Command grade the changes implemented at the War Studies University?

The knowledge about the problem situation allowed to specify the working hypotheses. The likely answer, being the solution to the main research problem, took the form of the main research hypothesis:

I assume that students of the Faculty of Management and Command perceive changes in the organizational culture of the War Studies University, especially such as: changes introduced to the name of the University, its structure, physical artefacts (emblem, banner, logo), significant events for the University, as well as in such cultural factors organizational, such as symbols, means of communication, values, myths and taboos.

As part of the research, it was assumed that the acquisition of empirical material will occur as a result of conducting surveys at the War Studies University at the Faculty of Management and Command.

The condition for effective solution of formulated research problems and verification of accepted hypotheses is the proper selection of research methods, techniques and tools. The following empirical research methods were used: opinion research - the technique used was surveying, and the tool used to collect data was the questionnaire. 


\section{Organizational culture - theoretical approach}

There are many definitions of organizational culture in the literature on the subject. In this study, it is not possible to cite them all, so for the purposes of this article one of many definitions adopted after D. Denison, who claims that organizational culture refers to a deeply hidden organizational structure based on values, beliefs and assumptions represented by employees, was adopted. The meaning is established through socialization within groups of different identities that coexist in the workplace. Through interactions, a world of symbols is built, which, on the one hand, provides culture with great stability, and on the other hand, gives it a certain fragility and instability resulting from the dependence of the system on individual behavior and cognitive processes (Paliszkiewicz, 2010, p. 220).

As A. Sitko-Lutek writes, the researchers' agreement on this concept refers to three issues, namely: the existence of organizational culture, its uniqueness for each organization and its role in building desired organizational behavior, internal identity and image (Sitko-Lutek, 2018, p. 50).

Of course, in the literature on the subject you can find manifestations of organizational culture and according to L. Ziegień-Maciąg there are: symbols, ways of communication, rituals, values, myths and taboos (Zbiegień-Maciąg, 2005, p. 43-50). They were used by the author of the article to study at the War Studies University.

One can also refer to the classic approach to organizational culture presented by E.H. Schein, who distinguished three basic levels, namely:

- visible artifacts and cultural creations,

— beliefs and values,

— basic assumptions (Sitko-Lutek, 2018, p. 57; Cameron, Quinn, 2015, p. 29).

First of these are artifacts and cultural products - the most visible manifestations of culture, which include language, art, architecture and other material products, as well as the visible structure of interpersonal relationships and the location of various social roles in it, such as gender, age roles, social class etc.

The second level are norms and values - rules that determine what is important for people in a culture, how they should be done and what should not be done, principles, morality and ethics of culture that direct both the goals of the community and the means by which they can be achieved.

The third and most deeply placed level in the cultural system are the basic assumptions and premises: fundamental, unconscious assumptions about the nature of truth and reality of human nature, the relationship between man and nature, the relationship between man and man, as well as the nature of time and space (Kostera, 2010, p. 150-151). It can be stated that this is the approach that was used to prepare this study. 
Following to K.S. Cameron and R.E. Quinn, changes in the organization are necessary due to the scope and the violence of the environment, and the conditions in which they are forced to function force organizations to react, because lack of reaction can lead to collapse (Cameron, Quinn, 2015, p. 21). Hence the inspiration to research, in relation to the changes carried out since 2016 at the War Studies University.

\section{War Studies University - characteristics of the university}

On October 1, 2016, pursuant to the adopted Act, War Studies University was established. The university is the heir to the achievements of previous institutions, it still educates officers for the needs of commands, staffs, military and civil institutions related to state defense. Civil youth prepares for public tasks, especially in the field of national security and the crisis response system. War Studies University is a continuator of the tradition of the Military Applicative School (1820-1831) and the College of War (1919-1946) (http://www.akademia.mil.pl/...).

Preserving the heritage of generations, the War Studies University sets new directions for the development of military thought by conducting innovative research, high quality education and the use of contemporary knowledge and practice of martial art, thus responding to the current and future needs of the Armed Forces.

What is more, the University contributes to the development and consolidation of military security of the Republic of Poland, the European Union and NATO through expert activities and research in the discipline of security and defense sciences, as well as shaping patriotic attitudes and respecting national traditions.

The University implements these tasks based on the highest ethical and civic values, such as: the pursuit of truth, respect for knowledge, patriotism, reliability, openness to new ideas and respect for man.

Education within the system of professional development of Polish Army officers takes place at the Military Faculty, whose potential is mainly academic teachers in active service, characterized by high quality of both theoretical and practical preparation.

The University also provides civil education at first, second and third degree, and postgraduate studies. After organizational changes, the University has three faculties: the National Security Department, the Management and Command Department and the Military Department.

The University's structures include the only in Poland and one of the most modern in Europe Center for Simulation and Computer War Games, specialized Training Center for Defense against Weapons of Mass Destruction, as well as the Security Research Center, which is a center of analysis and expertise for the needs of public authorities. Students have at their disposal modern lecture halls and laboratories, 12 conference rooms, a computerized library 
with nearly one million volumes, an internet reading room, nearly 1000 hotel and dormitory places, an academic canteen, a restaurant and a rich sport infrastructure: sports halls, indoor swimming pool, sauna, gym, sports stadium with athletics track and tennis courts. Students may also participate in the exchange of partner foreign universities as part of the Erasmus + program (http://www.akademia.mil.pl/...).

\section{Analysis of own research results}

The study involved 114 second degree students, full-time 61 students (53.51\%) and part-time 53 people (46.49\%) of the Faculty of Management and Command at the War Studies University. The study was conducted in June 2019.

The first physical artifact that the respondents were asked to have was symbols, all of them directly associated with the War Studies University, namely: banner, emblem, sign, logo, medals, rings, but also the mascot and features characteristic of the University's buildings. The respondents concluded that for 59 people $(51.75 \%)$ it is an important element of the organizational culture of the War Studies University, for 29 people $(25.44 \%)$ it is a very important element, for 19 respondents $(16.67 \%)$ it is an avarege import ant element, while for 4 people $(3.51 \%)$ and 3 respondents $(2.63 \%)$, this is not so or unimportant element. The results of the tests are presented graphically in the table number 1.

\section{Table 1.}

Symbols - as an expression of the organizational culture of War Studies University

\begin{tabular}{|l|r|r|}
\hline Category & $\mathbf{n}$ & \% \\
\hline very important & 29 & $25,44 \%$ \\
\hline important & 59 & $51,75 \%$ \\
\hline average important & 19 & $16,67 \%$ \\
\hline not so important & 4 & $3,51 \%$ \\
\hline unimportant & 3 & $2,63 \%$ \\
\hline & 114 & $100,00 \%$ \\
\hline
\end{tabular}

Source: own research.

Another element mentioned by the respondents were the ways of communicating in War Studies University, namely the extent to which in their opinion the recollection of communication is formalized or less formal. In the respondents' opinion, this element of organizational culture is very important for 53 people $(46.49 \%)$, for 40 respondents $(35.09 \%)$ it is important, and for 17 respondents $(14.91 \%)$ it is average important, while for 3 persons $(2.63 \%)$ and 1 person $(0.88 \%)$ are not so and unimportant element. The results of the tests are presented graphically in the table number 2. 
Table 2.

Means of communication - as a manifestation of the organizational culture of War Studies University

\begin{tabular}{|l|r|r|}
\hline Category & n & \% \\
\hline very important & 40 & $35,09 \%$ \\
\hline important & 53 & $46,49 \%$ \\
\hline average important & 17 & $14,91 \%$ \\
\hline not so important & 3 & $2,63 \%$ \\
\hline unimportant & 1 & $0,88 \%$ \\
\hline & 114 & $100,00 \%$ \\
\hline
\end{tabular}

Source: own research.

The next item that respondents were asked about was rituals in the sense of the word, as regards welcoming methods, certain rules of behavior characteristic of a civil-military university, as well as ways of celebrating both national and church holidays. And so, for 44 people (38.60\%) it is an important element, and 39 respondents $(34.21 \%)$ it is an average important element, for 16 respondents $(14.04 \%)$ it is very important, while for 12 people $(10.53 \%)$ and for 3 respondents (2.64\%) this is an element which is of little importance and is not important. The results of the tests are presented graphically in the table number 3 .

\section{Table 3.}

Rituals - as a manifestation of the organizational culture of War Studies University

\begin{tabular}{|l|r|r|}
\hline Category & $\mathbf{n}$ & \% \\
\hline very important & 16 & $14,04 \%$ \\
\hline important & 44 & $38,60 \%$ \\
\hline average important & 39 & $34,21 \%$ \\
\hline not so important & 12 & $10,53 \%$ \\
\hline unimportant & 3 & $2,63 \%$ \\
\hline & 114 & $100,00 \%$ \\
\hline
\end{tabular}

Source: own research.

When it comes to values, the respondents concluded that for them it is a very important element - 55 people $(48.25 \%)$, for 45 respondents $(39.47 \%)$ it is an important element, while for 11 respondents $(9.65 \%), 2$ people $(1.75 \%)$ and for 1 person $(0.88 \%)$ are respectively avarage, not so important or unimportant. The results of the tests are presented graphically in the table number 4 .

Table 4.

Values - as a manifestation of the organizational culture of War Studies University

\begin{tabular}{|l|r|r|}
\hline Category & $\mathbf{n}$ & \% \\
\hline very important & 55 & $48,25 \%$ \\
\hline important & 45 & $39,47 \%$ \\
\hline average important & 11 & $9,65 \%$ \\
\hline not so important & 1 & $0,88 \%$ \\
\hline unimportant & 2 & $1,75 \%$ \\
\hline & 114 & $100,00 \%$ \\
\hline
\end{tabular}

Source: own research. 
Next, the surveyed students were asked to respond to myths that can be heard at the University on equally topics, starting with students and ending with administrative staff and academic teachers. Respondents stated that this element is on average important for 40 respondents $(35.09 \%)$, for 32 people $(28.07 \%)$ it is not so important, while for 24 people $(21.05 \%)$ it is important, and for 13 respondents $(11.40 \%)$ it is an unimportant element, and for 5 people $(4.39 \%)$ it is very important. The results of the tests are presented graphically in the table number 5 .

\section{Table 5.}

Myths - as a manifestation of the organizational culture of War Studies University

\begin{tabular}{|l|r|r|}
\hline Category & n & \% \\
\hline very important & 5 & $4,39 \%$ \\
\hline important & 24 & $21,05 \%$ \\
\hline average important & 40 & $35,09 \%$ \\
\hline not so important & 32 & $28,07 \%$ \\
\hline unimportant & 13 & $11,40 \%$ \\
\hline
\end{tabular}

Source: own research.

The last element is tabor - the issues that are not mentioned in the opinion of the academic community, such as salaries, romances, etc. In the respondents' opinion, this is an element which is average important for 44 respondents (38.60\%), for 33 respondents $(28.95 \%)$ is not so important element, for 15 people $(13.16 \%)$ it is an important element, while for 12 people $(10.53 \%)$ it is an unimportant element. For 10 respondents $(8.77 \%)$ it is a very important element. The results of the tests are presented graphically in the table number 6 .

Tabela 6.

Taboo - as a manifestation of the organizational culture of War Studies University

\begin{tabular}{|l|r|r|}
\hline Category & n & $\%$ \\
\hline very important & 10 & $8,77 \%$ \\
\hline important & 15 & $13,16 \%$ \\
\hline average important & 44 & $38,60 \%$ \\
\hline not so important & 33 & $28,95 \%$ \\
\hline unimportant & 12 & $10,53 \%$ \\
\hline & 114 & $100,00 \%$ \\
\hline
\end{tabular}

Source: own research.

Summing up, the presented answers to the questions about the elements of War Studies University organizational culture, it can be said that in the respondents' opinion they are important or very important, especially when it comes to such elements as symbols, methods of communication, rituals and values. When it comes to the perception of such elements as myths and taboos, the respondents indicated that they are an element which is average important, of little importance or of no importance. This may indicate that in the short, because only 3 years time, they did not manage to form or did not yet become well established in the minds of respondents. 
Then the surveyed students were asked how they assess changes in the quality of education of War Studies University students. 65 people (57.02\%) considered it to be an important change that affects the functioning of the University. For 29 respondents $(25.44 \%)$ it is a very important change, for 12 people (10.53\%) it is on average level, and for 6 people $(5.26 \%)$ and for 2 people $(1.75 \%$ respectively) is a minor. The results of the tests are presented graphically in the table number 7 .

\section{Table 7.}

Change in the quality of education of War Studies University in the respondents' opinion

\begin{tabular}{|l|r|r|}
\hline Category & $\mathbf{n}$ & $\%$ \\
\hline very important & 29 & $25,44 \%$ \\
\hline important & 65 & $57,02 \%$ \\
\hline average important & 12 & $10,53 \%$ \\
\hline not so important & 2 & $1,75 \%$ \\
\hline unimportant & 6 & $5,26 \%$ \\
\hline
\end{tabular}

Source: own research.

Respondents were also asked about how they assess the changes made to the education programs. And so: 60 respondents $(52.63 \%)$ considered it to be an important change, for 23 people (20.18\%) it was a very important change, for 18 respondents $(15.79 \%)$ it was an average and appropriate change for 8 people $(7.02 \%)$ and for 5 people $(4.39 \%)$ this is a minor change and unimportant. The results of the tests are presented graphically in the table 8 .

Table 8.

Changes in study programs at War Studies University

\begin{tabular}{|l|r|r|}
\hline Category & $\mathbf{n}$ & \% \\
\hline very important & 23 & $20,18 \%$ \\
\hline important & 60 & $52,63 \%$ \\
\hline average important & 18 & $15,79 \%$ \\
\hline not so important & 8 & $7,02 \%$ \\
\hline unimportant & 5 & $4,39 \%$ \\
\hline
\end{tabular}

Source: own research.

Next, students were asked how they assessed the change in their expectations regarding the work done by academic teachers employed at War Studies University. It turns out that for 57 people $(50.00 \%)$ this is an important change, for 26 respondents $(22.81 \%)$ it is a very important change, and for 23 people $(20.18 \%)$ it is moderately important. However, in the opinion of 5 people $(4.39 \%)$ and 3 people (2.63\%), respectively, this is an unimportant or not so important change. Graphically, the results of the research are presented in the table number 9 . 
Table 9.

Change in students' expectations of academic teachers

\begin{tabular}{|l|r|r|}
\hline Category & n & \% \\
\hline very important & 26 & $22,81 \%$ \\
\hline important & 57 & $50,00 \%$ \\
\hline average important & 23 & $20,18 \%$ \\
\hline not so important & 3 & $2,63 \%$ \\
\hline unimportant & 5 & $4,39 \%$ \\
\hline
\end{tabular}

Source: own research.

The respondents were also asked about how they would assess the changes that were introduced in the organizational structure of the University - for example a change in the number of faculties, the emergence of a central dean's office, so the respondents stated that for 42 people (36.84\%) it is an important change, for 36 people $(31.58 \%)$ it is an change on average importance level, while for 22 people $(19.30 \%)$ it is very important, and for 8 respondents $(7.02 \%)$ it is unimportant, and for 6 people $(5.26 \%)$ is a minor change. Graphically the results of the tests are shown in the table number 10.

Table 10.

Changes in the organizational structure of the University

\begin{tabular}{|l|r|r|}
\hline Category & n & \% \\
\hline very important & 22 & $19,30 \%$ \\
\hline important & 42 & $36,84 \%$ \\
\hline average important & 36 & $31,58 \%$ \\
\hline not so important & 6 & $5,26 \%$ \\
\hline unimportant & 8 & $7,02 \%$ \\
\hline & 114 & $100,00 \%$ \\
\hline
\end{tabular}

Source: own research.

In addition, the respondents were asked how they would evaluate the change, how it took place in the position of Rector-Commander, 46 people $(40.35 \%)$ considered that this is an average important change, for 29 people $(25.44 \%)$ it is an important change, and for 16 people $(14.04 \%)$ this is a minor change. Subsequently, the respondents stated that for 12 people $(10.53 \%)$ this was an unimportant change, and for 11 respondents $(9.65 \%)$ a very important change. The results of the tests are presented graphically in the table number 11.

Table 11.

Change in the position of Rector-Commander of the War Studies University

\begin{tabular}{|l|r|r|}
\hline Category & $\mathbf{n}$ & $\mathbf{\%}$ \\
\hline very important & 11 & $9,65 \%$ \\
\hline important & 29 & $25,44 \%$ \\
\hline average important & 46 & $40,35 \%$ \\
\hline not so important & 16 & $14,04 \%$ \\
\hline unimportant & 12 & $10,53 \%$ \\
\hline & 114 & $100,00 \%$ \\
\hline
\end{tabular}

Source: own research. 
The respondents were also asked about a change in the position of the Minister of National Defense, because it seems that due to the fact that the University falls under both the Ministry of National Defense and the Ministry of Science and Higher Education, it seems reasonable to ask respondents about it. And so: 38 people (33.33\%) is an important change, for 27 respondents $(23.68 \%)$ it is an average important change, for 24 respondents $(21.05 \%)$ it is a very important change, and for 13 respondents (11.04\%) is an unimportant change and for 12 people $(10.53 \%)$ it is a not so important change. The results of the tests are presented graphically in the table number 12 .

\section{Table 12.}

Change in the position of the Minister of National Defense

\begin{tabular}{|l|r|r|}
\hline Category & n & \% \\
\hline very important & 24 & $21,05 \%$ \\
\hline important & 38 & $33,33 \%$ \\
\hline average important & 27 & $23,68 \%$ \\
\hline not so important & 12 & $10,53 \%$ \\
\hline unimportant & 13 & $11,40 \%$ \\
\hline & 114 & $100,00 \%$ \\
\hline
\end{tabular}

Source: own research.

To sum up this part of the answers, it can be stated that for the students, changes that have a direct impact on their functioning as a student are usually important and very important: changes in the quality of education of War Studies University students, changes made in education programs, changes in study programs, changes introduced in the organizational structure of the University, changes in relation to expectations of academic teachers. On the other hand, the changes in the position of Rector-Commandant and Minister of National Defense were considered to be of average importance. On this basis, it can be concluded that the changes introduced at the University, which affect their functioning at the University, are more important for students. On the other hand, those that do not have a direct impact in their opinion are assessed as moderately important or less important.

The next question indicates several categories that were intended to help respondents refer to the issue of changes that take place at the University after its transformation, especially in relations with the external environment. And so, the respondents concluded that for 42 people (36.84\%) they observe significant changes in this area, while 36 people $(31.58 \%)$ had no opinion on this subject, for 22 respondents $(19.30 \%)$ it was a situation in which they did not observe significant changes in the University's relations with the external environment, and 11 respondents $(9.65 \%)$ is a situation in which there were changes in external relations and noticed a significant opening of the University to the mentioned relationship building, while 3 people (2.63\%) recognized that the University is still closed to the external environment and does not build new relations with it that could contribute to its development and further changes. The results of the tests are presented graphically in the table number 13 . 


\section{Table 13.}

Contacts with the external environment of War Studies University

\begin{tabular}{|l|r|r|}
\hline Category & n & \% \\
\hline Very good, I see the Univeristy's opening to the external environment & 42 & $9,65 \%$ \\
\hline Good, I'm observing significant changes in this area & 36 & $36,84 \%$ \\
\hline I don't mind & 22 & $31,58 \%$ \\
\hline $\begin{array}{l}\text { Bad, I didn't notice any significant changes in relations between the } \\
\text { University and the external environment }\end{array}$ & 3 & $19,30 \%$ \\
\hline $\begin{array}{l}\text { Very bad, I think that the University is still closed to the external } \\
\text { environment }\end{array}$ & 114 & $2,63 \%$ \\
\hline
\end{tabular}

Source: own research.

Next, the respondents were asked about how they assess the well-known ones that take place at the University after its transformation from the National Defense University into the War Studies University. It turns out that the respondents concluded that 58 people $(50.88 \%)$ did not notice any significant changes related to this, and 21 people (18.42\%) admitted that they noticed a significant reduction in the quality of the University's functioning, for 20 people $(17.54 \%)$ is better than it was, and for 13 respondents $(11.40 \%)$ it is very bad and they did not notice any significant changes improving the functioning of the University, 2 people $(1.75 \%)$ considered it better than before making changes. The results of the tests are presented graphically in the table number 14.

\section{Table 14.}

Assessment of changes after transformation of the University

\begin{tabular}{|c|c|c|}
\hline Category & n & $\%$ \\
\hline $\begin{array}{l}\text { Very good, the changes introduced have contributed to improving } \\
\text { the functioning of the University }\end{array}$ & 2 & $1,75 \%$ \\
\hline Good, it's better than before changes & 20 & $17,54 \%$ \\
\hline $\begin{array}{l}\text { I didn't notice any impact of changes on the functioning of the } \\
\text { University }\end{array}$ & 58 & $50,88 \%$ \\
\hline Bad, I see a decrease in the quality / efficiency of the University & 21 & $18,42 \%$ \\
\hline $\begin{array}{l}\text { Very bad, I noticed that it is worse than before the changes in the } \\
\text { university }\end{array}$ & 13 & $11,40 \%$ \\
\hline & 114 & $100,00 \%$ \\
\hline
\end{tabular}

Source: own research.

Summing up this part, it can be stated that students are quite critical of the changes they make at the University, are vigilant and try to follow what is happening at the University. Therefore, on the one hand, they positively assess the changes regarding the University's opening to the external environment, probably in connection with numerous exchanges under the ERASUS program, but also in connection with the numerous agreements signed with other Universities and companies where professional experience can be gained. On the other hand, students are very critical for the whole change, namely that nothing has changed in the quality and efficiency of the University. This may be directly related to the fact that these changes have been introduced relatively recently. 
To sum up, it can be said that for the respondents, the changes that were introduced at the University, as a result of its transformation from the National Defense University into the War Studies University and factors specific to organizational culture are important. It seems that students pay close attention to what is happening at the University, as well as in the external environment with which learning cooperates. Students closely follow the changes in law and in the University itself, because it directly determines their functioning as a student. And at the same time it can have a significant impact on their perception by employers on the labor market.

\section{Conclusion}

The assumed goal of the article was looking for answers to the main research problem in the form of a question:

How are changes in the organizational culture of the War Studies University perceived by students of the Faculty of Management and Command?

It can be said that students of the Faculty of Management and Command are able to identify, perceive those factors, elements and events that have a direct impact on the functioning of students in their role, while assessing these changes as important or very important.

In regard to the first detailed problem concerning the answer to the question about elements of the War Studies University organizational culture, it can be stated that in the respondents' opinion they are important or very important, especially when it comes to such elements as symbols, methods of communication, rituals and values. When it comes to the perception of such elements as myths and taboo, the respondents indicated that they are of average importance for them, not so important or unimportant.

In the context of the second detailed problem concerning changes at the University, it was found that for the students the changes that have a direct impact on their functioning as a student are usually important and very important. At the same time, students are quite critical of the changes they make at the University, they are vigilant and try to follow what is happening at the University.

Based on the above results of empirical research, it can be concluded that a positive verification of the working hypothesis made for the purposes of this article has been made. The author of the work is aware of the fact that the obtained research results are not representative and should not be generalized in the context of all students of the War Studies University. Nevertheless, the collected empirical data shows the need for more extensive research in this area and the opinion to include students of other Military and National Security Faculties in the study. It also seems reasonable to undertake research among teacher employees employed at the University and administrative staff to obtain empirical data on how they perceive changes at the University and their impact on the University's organizational culture. 


\section{References}

1. Cameron, K.S., Quinn, R.E. (2015). Kultura organizacyjna - diagnoza i zmiana. Model wartości konkurujących. Warsaw: Wolters Kluwer.

2. Kostera, M. (2010). Tworzenie kultury organizacyjnej. In: J. Bogdanienko, Organizacja i zarzadzanie w zarysie. Warsaw: Wydziału Zarządzania Uniwersytetu Warszawskiego.

3. Niemiec, M. (2015). Teoretyczne i praktyczne aspekty kultury organizacyjnej $w$ środowisku wojskowym. Warsaw: AON.

4. Paliszkiewicz, J.O. (2010). Kultura oparta na zaufaniu. In: E. Skrzypek E. (ed.), Etyka a jakość i efektywność organizacji. Lublin: UMCS.

5. Sitko-Lutek, A. (2018). Aspekty złożoności kultury organizacyjnej. Lublin: UMSC.

6. War Studies University. Między tradycja a przyszłościa, Retrieved from http://www.akademia.mil.pl/historia-zadania/detail,nID,1324, 06.09.2019.

7. War Studies University. Zadania akademii sztuki wojennej, Retrieved from http://www.akademia.mil.pl/historia-zadania/detail,nID,1324, 06.09.2019.

8. Zbiegień-Maciąg, L. (2005). Kultura $w$ organizacji. Identyfikacja kultur znanych firm. Warsaw: PWN. 